\title{
The Principles of Sustainable Development and the Possibilities of Limiting the Global Effects of Smog by Medium-sized Cities Located in the European Union on the Example of Mikołów (Poland) and Żylina (Slovakia)
}

\section{Zasady zrównoważonego rozwoju a możliwości ograniczenia globalnych skutków smogu przez miasta średniej wielkości zlokalizowane w Unii Europejskiej na przykładzie Mikołowa (Polska) i Żyliny (Słowacja)}

\author{
Michał Czuba \\ Uniwersytet Śląski w Katowicach, Wydział Nauk Społecznych, Instytut Nauk Politycznych \\ ul Bankowa 12 40-007 Katowice, Poland \\ E-mail: phdmczuba@o2.pl
}

\begin{abstract}
The urban smog has negative global effects. They are expressed in the increased mortality of people, an increase scale of respiratory diseases as well as climate changes causing negative effects in the field of agricultural crops, which results in an increase in food prices. The occurrence of these phenomena mobilizes the global community to conduct activities aimed at limiting their occurrence. Medium-sized cities can play a significant role in this respect.

The element conditioning the life of city dwellers is the appropriate condition of the natural environment. In Polish and Slovak conditions, smog is becoming a problem, which negatively affects the health of citizens of these countries. Therefore, actions are taken to limit the occurrence of this phenomenon. They are described in the current ecological policy of both countries.

This article tries to show on the example of the Polish commune of Mikołów and the Slovak commune of Żylina the actions taken in them to reduce air pollution and thereby reduce the phenomenon of smog. In both analysed cities, measures taken to reduce the phenomenon of smog are implemented in a planned manner and may be an inspiration for other medium-sized cities in the world having air quality problems.
\end{abstract}

Key words: global effects of smog, medium-sized cities, environmental policy, urban smog, smog prevention, health

\section{Streszczenie}

Występowanie smogu przynosi ujemne globalne skutki. Wyrażają się one zwiększoną śmiertelnością osób, zwiększaniem się zapadalności na choroby dróg oddechowych a także zmianami klimatycznymi wywołującymi negatywne skutki w dziedzinie plonów rolnych co skutkuje wzrostem cen żywności. Skala tych zjawisk mobilizuje społeczność światową do prowadzenia działań mających ograniczyć ich występowanie. Znaczną rolę w tym zakresie mogą odgrywać miasta średniej wielkości.

Elementem warunkującym życie mieszkańców miast jest odpowiedni stan środowiska naturalnego. W warunkach polskich i słowackich problemem staje się zjawisko smogu, które w ujemny sposób wpływa na zdrowie obywateli tych państw. Podejmowane są w związku z tym działania mające na celu ograniczyć występowanie tego zjawiska. Wpisane są one w obecną politykę ekologiczną obu państw. 
Niniejszy artykuł próbuje pokazać na przykładzie polskiej gminy Mikołów i słowackiej gminy Żylina podejmowane w nich działania mające na celu ograniczyć zanieczyszczenie powietrza i tym samym zmniejszyć zjawisko smogu. W przypadku obu analizowanych miast podejmowane działania zmniejszające zjawisko smogu są realizowane w sposób planowy i mogą stanowić inspirację dla innych miast średniej wielkości na świecie, mających problemy z jakością powietrza.

Słowa kluczowe: globalne skutki smogu, miasta średniej wielkości, polityka ekologiczna, smog miejski, zapobieganie smogowi, zdrowie

\section{Introduction}

Urban agglomerations have problems related to air quality. Its pollution has a negative effect on human health, and also contributes to negative climatic phenomena. Polluted air also reduces agricultural yields (Shindell et al., 2012).

For a long time, London was a city that had good and unpolluted air. This was until the spring in 1952, when for four consecutive days smog persisted in it, which was called the great smog. It caused the death of about 4.000 adults. A similar phenomenon occurred in Los Angeles in the 1940s. The appearance of urban smog has caused the change in the legal regulations of England and the United States, and then in other countries around the world. They aimed at the planned control of the quality of air (Melamed, Zhu, Jalkanen, 2013).

The problem of urban smog and polluted air is manifested by the negative impact on the health of people living in large urban centres. The OECD (Organisation for Economic Co-operation and Development) report indicates that by 2050 contaminated air will be the largest external factor contributing to human mortality on an equal footing with contaminated water or lack of sanitary sewage (OECD 2012). It can be concluded that human health depends on air quality and the absence of urban smog.

The problem of urban smog is not only found in large cities. Increasingly, it affects small and mediumsized towns. It is a growing challenge for European cities, including Polish and Slovak. Due to the increasing intensity and its global effects, it has become part of the environmental policy of the European Union Member States.

\section{Global effects of urban smog}

$84 \%$ of the world's population breathes polluted air. Annually, 3 million people die of smog, compared to 1.3 million who die in traffic accidents. Air pollution is classified by the WHO as one of the most important health risk factors in the world. It is ranked $4^{\text {th }}$ among the 10 most important global risk factors related to behaviour, environment, work and metabolism. The greater health risks are only a poor diet based on highly processed products, smoking and high blood pressure (Deloitte-Sustainability Insights, 2017).

Smog is ranked $5^{\text {th }}$ among the most harmful factors contributing to death in the world (Special Report On
Global Exposure To Air Pollution \& Its Disease Burden IHME, 2019). Prolonged exposure to polluted air impairs the defences of the respiratory tract, paving the way for infections, and also hinders has exchange in the lungs, which causes a greater burden on the heart. Breathing polluted air contributes to the development of many dangerous diseases related to the respiratory system (asthma, respiratory failure, bronchitis, lung diseases), the circulatory system (heart attack, embolism, stroke, chest pain), and cancer.

The particles that make up smog constitute the socalled climatic factors. They affect the amount of solar energy (including heat) that the Earth retains, and the amount of energy that is sent back into space. Climatic factors include the most important air pollutants such as ozone, methane, particulate matter and nitrous oxide. Particulate matter is a complex pollutant. Depending on its composition, it can have a cooling or warming effect on local and global climate. Other types of PM containing sulphur or nitrogen compounds have the opposite effect. As a rule, they act as small mirrors reflecting solar energy, which in turn leads to a cooling of the climate. Simply put, it all depends on the colour of the particle. White particles usually reflect sunlight, while black or brown particles absorb them. A similar phenomena can be observed on land. Some particles settle together with rains or snow, or simply settle on the surface of the ground. For example, black carbon, which is one of the components of fine particulate matter (PM) and is formed as a product of incomplete combustion of fuels, absorbs solar and infrared radiation in the atmosphere, affecting global warming. Other types of PM containing sulphur or nitrogen compounds have the opposite effect. As a rule, they act as small mirrors reflecting solar energy, which in turn leads to a cooling of the climate.

The colour of particles suspended in the air or settling on the ground is not the only property that can affect the climate. The air consists partly of water vapour - tine water molecules suspended in the air. Clouds are a more condensed form of water vapour. These particles play an important role in the cloud formation process; they affect their durability and the ability to reflect solar radiation; they determine the type of precipitation generated by a given cloud, the place of occurrence of such precipitation, etc. It is obvious that clouds are crucial to our climate; the concentration and composition of particulate matter may affect the date and distribution of traditional precipitation systems. 
Changes in the abundance and frequency of precipitation are associated with real economic and social costs, as they usually have an impact on global food production and, consequently, on its price ((Zmiana klimatu a powietrze, 2016).

\section{The principles of sustainable development and the problem of smog}

In the process of sustainable development, not only material development, but also intellectual and spiritual development of man is important. Therefore, it is about re-evaluating the current lifestyle and introducing a person who is aware to a path of development, leading towards quality rather than quantity (Skowroński, 2006, p. 51).

The essence of sustainable development is to reconcile ecological, economic and social reasons. The assumptions of this concept come down to three basic goals:

1) ecological - consisting in stopping the degradation of the environment and eliminating its threats,

2) economic - seeking to meet the basic material needs of humanity using the techniques and technologies that do not damage the environment, and

3) social and humanitarian - which focuses on securing the social minimum (ending hunger, misery and poverty), health protection, development of the human spiritual sphere (culture), security and education (Machowski, 2003, p. 100101).

The problem of urban smog is associated with the first goal of the analysed concept. It leads to degradation of the natural environment. It also has references to the second of the mentioned goals of the sustainable development. Urban smog is partly the result of the communication needs of city dwellers, business activities and living needs related to heating homes and flats in the winter period. Modern heating technologies and the increasing use of electric buses in public transport come to the rescue against smog. The occurrence of urban smog is also related to the third of the above-mentioned goals of sustainable development. This phenomenon causes negative social effects which are particularly damaging to the health of residents of smoky cities and thus to health care. In 2015, the United Nations General Assembly adopted 17 goals that set out the direction of efforts for a better life and a cleaner environment. They are the content of the 2030 Agenda - a global plan for sustainable development.

The current lifestyle using the Earth's natural resources intensively had led to more production and consumption than ever before. A larger number of toxic chemicals and particulates present in the air became the by-products of production and consumption processes. In turn, increased greenhouse gas emissions to the Earth's atmosphere from manufacturing activities caused dangerous climate change. Climate change and air pollution are interrelated. By limiting air pollution, negative climate change can be countered.

Actions aimed at reducing air pollution and thus the phenomenon of urban smog are an important part of the 2030 Agenda indicated above. They constitute the specification of 17 goals set out in it. The problem of air pollution and smog is determined by specific tasks related to the implementation of Objective number 12 (Responsible consumption and production) and 13 (Climate action). Taking action to reduce air pollution, on the other hand, implements the assumption of Objective 3 (Good health and quality of life), and also inclines to actions postulated in $\mathrm{Ob}-$ jectives: 7 (clean and available energy), 9 (Innovation, industry, infrastructure) and 11 (Sustainable cities and communities). Building a circular economy to lead to the effective management of Earth's resources, supports the protection of biodiversity and measures necessary to preserve the natural environment in water and on land, which also has an impact on air quality (Objectives 14 and 15) (UN, 2015).

\section{The problem of urban smog and directions of sci- entific research related to it}

The World Health Organization recognizes each substance that has a harmful effect on health or is dangerous for other reasons, regardless of the physical form of the substance, as air pollution (Krzyżanowski, 2008, p. 47-50). The phenomenon of urban smog accumulates these pollutants, in the long run leading to negative health effects or even death. So one can talk about the catastrophic effects of urban smog, which are greater the longer it lasts in a given territory.

Taking into account the Polish perspective as the main source of air pollution, anthropogenic emissions resulting from coal combustion in central heating furnaces by homeowners and from industrial activities, as well as those resulting from emissions from public transport are indicated. One of the features of air pollution is the possibility of their movement. The fuel and energy, as well as metallurgy industries are largely responsible for dust pollutions that contributes to the formation of smog in Poland (Malec, Borkowski, 2016, p. 161-170)

In relations to smog, there are a lot of studies on the problems that are raised by this phenomenon in large urban agglomerations. A good example illustrating this direction of research are works devoted to the occurrence of smog in various provinces and areas of China in a social context (Zhou, Dai, 2017).

Another research direction related to the issue of smog is focused on designing and developing the functionality of air pollution monitoring systems in cities and notifying their residents about the level of pollution (Rhode, Muller, 2015). 
Research in the field of urban smog also takes into account the activity of citizens and non-governmental organizations in the field of environmental education regarding the harmfulness of polluted air and the possibilities of preventing this phenomenon (Gallet 2018, Hernandez, 2015).

\section{Current ecological policy of Poland and Slovakia and the problem of urban smog}

On February 14, 2017, the Council of Ministers adopted a new medium-term national development strategy - Strategy for Responsible Development until 2020 (with a perspective until 2030) - SRD. The strategic goals, activities and projects indicated therein were to be reflected in all Poland's strategic documents and thus also the environmental strategy. As a result of the work of the Ministry of Environment, a new document was created, which was named the 2039 Ecological State Policy 2030 (ESP). It takes into account the problem of air pollution in Poland and its causes.

The priority of the new ecological policy of Poland is to be the construction of an innovative economy while maintaining the principles of sustainable development, which are a requirement of modern state policy. It is man who is the supreme value in the 2030 Ecological State Policy by drawing attention to such issues as the quality of life, health and well-being of Poles. The key to achieving the goals of the new ecological policy is the proper use of the environment at the local government level, especially through rational spatial planning, which helps to protect the population against air and noise pollution and nature against excessive pressure of human activity.

Striving to improve the quality of life creates a constant need for development, which can only be achieved through the sustainable use of natural resources. None of the forms of human activity can cause permanent deterioration of natural resources. That is why the development process will be monitored by means of appropriate indicators enabling the assessment of such aspects as: the improvement of water and air quality, reduction of impact on climate change and preservation of the full species composition of native fauna and flora.

As part of the National Environmental Policy, actions are to be implemented until 2030 to improve the air quality by reducing low emissions. At the governmental level, they mean the preparation of relevant provisions and instruments for financial support for investments and coordination of their implementation in the regions.

In Poland, air, water and soil pollution have decreased since 1990 as a result of structural changes in the economy, the implementation of the state's environmental policy and its implementing programs with pro-environmental investments, and tightening the legal regulations. Effective management of in- dustrial emissions, especially from the energy sector, significantly reduced their share in exceeding air quality standards in Poland and allowed for a significant reduction in greenhouse gas emissions. However, effective climate protection requires further emission reduction, using constantly improved technical and natural methods.

The most important challenges in this area include the elimination of the so-called low emission, which is the result of the use of solid fuels (including lowquality coal) and waste is the domestic and municipal sector, primarily for individual heating of buildings, exploitation and technological maladjustment of furnaces and small local boiler rooms, as well as the low energy standard of buildings. In urban areas and along commuting routes, a significant share of air emissions from transport has a significant impact on air quality. Currently, regulations on emission standards for cars are adopted at the EU level, and activities in the field of electric means of transport are promoted at the national level (Uchwała Rady Ministrów z dnia 16 lipca 2019 r. w sprawie przyjęcia Polityki ekologicznej państwa 2030 strategia rozwoju $w$ obszarze środowiska i gospodarki wodnej, 2019).

In February 2019, Slovakia adopted a new Environmental Policy with a perspective until 2030. Its main element in the field of improving air quality are activities aimed at significantly reducing pollutant emissions over the period under analysis. The instruments that are currently used (emission limits, technical requirements and operating conditions) are insufficient. In the case of Slovakia, the national emission reduction program is to be key to achieving the commitment made. It refers to the main areas with the highest emission reduction potential, such as transport, household heating, agriculture, industry and energy. An effective measure contributing to the reduction of the smog phenomenon in Slovakia may also be the emission trading scheme, which is to help reduce emissions of a given pollutant taking into account the benefits of this title for the environment, society and the economy. This system would replace the current charging system and would be introduced for the pollutants that are the most problematic for Slovakia in terms of achieving the emission targets set.

Another element of the Slovak new environmental policy in the field of air protection is to be the dissemination of the latest combustion technologies. This is particularly relevant to industrial installations. The emerging new plants, especially mediumsized ones, will have to have documentation confirming that such installations are environmentally friendly and are based on the latest technological achievements limiting their negative impact on air quality.

As part of the adopted ecological policy, measures will be promoted in Slovakia aimed at switching households from the use of old heating appliances to 
solid fuel, which significantly contribute to air pollution, to more efficient heating installations. Emission standards and energy efficiency of combustion equipment, including used fuel, will also be monitored for small combustion installations. Illegal waste burning in domestic furnaces will be controlled by independent authorities and punished to avoid air pollution and damage to public health. At the same time, legislative and support mechanisms will be introduced to replace older, less energy-efficient heating devices that do not meet the latest emission standards. Market regulation will be introduced with heating devices up to $0.3 \mathrm{MW}$. Only devices that meet the new emission criteria will be available on the market. The population will be encouraged to use municipal heating plants whenever possible.

Another element of the currently implemented environmental policy of Slovakia are activities aimed at limiting the use of coal to generate heat and electricity.

As part of the ongoing environmental policy in Slovakia, low-emission transport based on electromobility and alternative fuels with a minimal impact on air quality will be promoted. Transport and in particular passenger cars have an increasing share in the total greenhouse gas emissions and other pollutants, in particular nitrogen oxides. It is responsible for almost half of all nitrogen oxide emissions. Low-emission public passenger transport and city bike rides will be preferred in urban areas of Slovakia. Longdistance public transport will promote low-emission public passenger transport, in particular railways, trams and electric buses. Municipalities will be able to charge owners of passenger cars for congestion and create conditions to limit car traffic, creating free zones. In addition, the cities will have different emission zones with access for vehicles that meet certain emission criteria. The tax system of Slovakia is already in favour to low-emission transport. In addition, vehicles negatively affecting the environment will be taxed higher (Greener Slovakia. Strategy of the Environmental Policy of the Slovak Republic until 2030).

\section{Research objectives and methods}

The cognitive goal of this article is to show measures to reduce the phenomenon of smog in medium-sized cities on the example of Mikołów and Żylina, taking into account the currently implemented ecological policy in Poland and Slovakia.

The theoretical goal is to indicate to what extent the activities related to smog in Mikołów and Żylina coincide with the main directions of research in this field conducted by scientists.

For the purposes of this study, the case study method was used. To prepare it, the so-called secondary research of documents, articles, analyses and press articles available on the Internet were used. The materials collected in this way allowed to com- prehensively describe the tasks and initiatives aimed at reducing the phenomenon of smog in the analysed cities.

\section{Actions to reduce the phenomenon of urban smog in Mikolów}

Mikołów is a town with 40,000 inhabitants located in the Silesian voivodeship in Poland. It is a town that aspires to develop with the principles of ecology and sustainable development. To realize this intention, various activities and projects allowing to achieve this goal have been implemented and promoted in the analysed city for many years (Czuba, 2018, p. 347-357).

In the autumn-winter period, the so-called problem of low emissions appears in Mikołów. Exhaust fumes from cars, dusts and gases emanating from domestic heating furnaces and coal boiler rooms are its source. The town wants to change this situation. In the municipal office, you can get a subsidy to replace the outdated source of heating the house with a more ecological one from the funds of the government's CLEAN AIR program.

However, human awareness plays the most important role in the fight against low emissions. More and more residents of Mikołów are aware of the need to burn the right quality coal.

In November 2016, the City Guard of Mikołów together with firefighters from the Volunteer Fire Brigade started a series of demonstrations of ecological coal burning. About 150 people took part in the first shows. Similar events were also carried out in nearby towns neighbouring Mikołów. During the shows, two identical furnaces were presented, with the same fuel, wood and coal of the same quality.

Traditional bottom combustion was used in the furnace producing smoke, while in the one with less smoke - upper combustion. The second method is more difficult to master because the furnace should be loaded with coal straight away, and only then the kindling is placed on it and the entire insert should burn out to the end.

This type of combustion produces much less smoke and the additional benefit comes in the form of more heat energy. The above mentioned furnace demonstrations are complemented by instructional companies regarding these issues. They can be viewed on the city guard website (city guard website from Mikołów, 2018)

In 2015, City Guards from Mikołów received over 100 reports due to excessive smoke. 84 burning controls were carried out and reports were drafted. At that time, it turned out that the reason for the smoke was inefficient coal burning, and only in a few cases it involved burning of unauthorized waste (Demski, 2016).

The new and aesthetic facades of the buildings are visible in several Mikołów housing estates. After renovation, heating the same buildings is cheaper 
and uses less fuel for this purpose, and therefore air pollution is also reduced. In 2018, dozens of buildings were thermo-modernized in Mikołów. Thanks to the revitalization of the city centre, tenement houses located in the town square and on the streets adjacent to it, which are currently heated with coal, will be connected to the municipal heating network and will stop producing smoke.

In mid-2018, the municipality of Mikołów also began installing solar installations. The mayor of this town raised over PLN 3.2 million from the European Union for this purpose. These funds will allow for the installation of ecological installations in 173 households in Mikołów. (Urząd Miasta Mikołów, 2018).

In 2018, the largest infrastructure investment began in Mikołów, i.e. the construction of a transfer centre. As a result, the vicinity of the station and the organization of traffic in this area will change. A large parking lot for cars and buses will be created to service the transfer centre. The changes are to serve better and more convenient travel by public transport. In addition, the Upper Silesian-Zagłębie Metropolis, of which Mikołów is a member, plans to purchase about 300 electric buses. They will drive residents of this town without the exhaust emissions that aggravate the smog phenomenon (Urząd Miasta Mikołów, 2018).

In addition to the aforementioned measures to reduce the phenomenon of smog, Zakład Inżynierii Miejskiej spółka z o.o. (ZIM), which is owned by Mikołów, in 2007-2013 carried out investments regarding the modernization of boiler rooms and heating installations.

As part of the project, heating mains along with technical infrastructure were rebuilt and built, and the existing heat exchanger stations were modernized. One of the two municipal boiler houses has also been modernized, as well as its dedusting and flue gas installation, and a new three-pipe chimney has been built in the modernized $60 \mathrm{~m}$ high heating plant (ZIM website).

The presented actions aimed at limiting the phenomenon of smog in Mikołów were planned and medium-term. In Mikołów, the public space has been striving to be ecological and aesthetic for many years. It is worth doing it because it is a common good. Therefore, it should be neat, aesthetic and have a positive impact on the environment which is inhabited by residents of this town.

\section{The problem of urban smog in the city of $\dot{Z} y$ lina in Slovakia}

Żylina is the fourth largest city in Slovakia with 80,000 inhabitants. It is an important administrative, business and industrial centre and the capital of the Żylina Region - a region bordering the Silesian and Lesser Poland voivodeships. It is located in a valley in which dirt is accumulated, including those flowing in from outside. The main transit car thoroughfares of a quasi-urban highway run through the centre of Żylina. What distinguishes Żylina from Polish cities is that legally none of its residents burns coal. The municipal heating network and gas heating are the foundations of heating, just like in other Slovak cities. Single-family houses on the outskirts of the city are heated with gas (it is cheaper than in Poland) or wood. Burning garbage in domestic boilers is a marginal phenomenon. However, the surrounding cities and villages are the problem. The nearby Kysuce region is one of the few in Slovakia, where heating of houses with coal is common (Orava is the second such region). It causes that during the heating period, the valley of Kysuce River is covered with smog from individual sources of emissions. The pollution generated in this way flows down to Żylina. In addition, there is quite a large inflow of pollution from abroad - mainly from the nearby Czech Silesia, including mainly from the metallurgic plants in Trinec. Pollution from the Czech Republic, Poland and Hungary also flows into Żylina. In order to learn the scale of this phenomenon in Slovakia, pollution measuring stations from border areas are to be installed in the border areas. One of the biggest sources of pollution is the local industry, including paper factories located near the centre of Żylina, commonly known as Celulozka. Despite the continuous improvement of technology, the plants are still polluting and are considered a larger ecological problem than local low emissions.

As part of the fight against smog in Żylina, actions are taken to organize and reduce car traffic. Żylina gives the impression of a city that is subordinate to cars. Transit car thoroughfares of a quasi-highway nature cross its centre. There is a huge noise everywhere, there is dust on the sidewalks, and a walk around the city is not very pleasant. The infrastructure for pedestrians and public transport passengers is also not conducive to giving up the car. The pavements in the centre are crooked, dirty and made of very unsightly paving. This is a sensation, because it other cities of Slovakia pavements are built of asphalt. The city, fighting pollution, follows the 2013 Air Quality Improvement Program. Its implementation includes: reducing the activity of the industry excessively polluting the air, development of bicycle transport, modernization of the trolleybus network, renewal of street greenery, revitalization and expansion of the existing parks, reconstruction of interblock greenery and increasing the area of green areas in the city. These activities are already visible in the city in question. Bike paths that are created in the blocks of flats and on the outskirts of the city look good. New pavements are currently being built exclusively from asphalt, which also promotes walking. Scooters are very popular in the city (in blocks of flats), especially as access to school, skateboards as well to a lesser extent. Both methods of transport require a smooth surface, mainly asphalt. According 
to the Slovak law, people on scooters and skateboards can move both on bike paths and on pavements. Outside the centre of Żylina, the conditions for cycling and scooters are good, but the closer it gets to the Old Town and the train station, the worse it gets.

In the case of Żylina or Slovak smog in general, the topic of low heating emissions does not appear at all. Not because it does not exist - limiting wood burning on the outskirts of the city would also significantly improve air quality, and the liquidation of smoking furnaces in the nearby villages of the Kysuce Nowe Miasto and Czadca would improve it even more. However, there is a lack of awareness that such a problem exists, monitoring stations, smog information campaigns, and scientific research. Smog itself is not negated, although it is several times smaller than in Poland. Activities in this field in the analysed city in the coming years will focus on transport. The motorway bypasses of Żylina will be competed in a few years. It can be expected that then the car traffic in the centre will be limited, which is even supported by the die-hard car supporters taking into account European trends in this area. Also the Slovak Air Act goes in this direction - one of its most important provisions is the establishment of lowemission zones in city centres, where cars that do not meet exhaust gas quality standards will not be allowed. Therefore, it can be expected that such a zone will be established soon in Żylina. (Loginow, 2017).

\section{Discussion}

Moving to the discussion on the case studies presented above, it can be stated that the actions taken in Mikołów to reduce the phenomenon of smog fit into the previously presented directions of scientific research in this field. However, the second perspective, concerning the research and development of pollution monitoring systems, is becoming particularly important. Mikołów has sensors located in its individual parts and the information derived from them is presented graphically on the Airly website. So far, however, no system of text notifications for residents has been created, providing information on the threat of smog.

In the case of the analysed Slovak city of Żylina, taking into account the outlined research perspectives on the phenomenon of smog, one can basically find a reference only to the issue of installing pollution sensors originating mainly from the countries bordering Slovakia. These actions are taken to determine the scale of imports of this type of pollution. In the case of Slovakia, there is basically no involvement of NGOs and citizens themselves in environmental issues. This element is different from the Polish specificity.

Despite the low environmental awareness, which is confirmed by research conducted in Poland, it begins to gradually increase (Płatkowska-Prokopczyk,
2017). Such changes can also be seen in the attitudes of the inhabitants of Mikołów, which are becoming more and more environmentally friendly. They are manifested in reporting suspected burning of illegal items in central heating furnaces or burning of poor quality coal. Their interest in the so-called top burning is growing, which is more ecological and causes much less exhaust gas. These attitudes correspond to the third research perspective presented in this study, related to the importance of social awareness and non-governmental organizations as important entities for reducing the phenomenon of smog. Local ecological organizations run various types of training directed at pupils and teachers of schools in Mikołów to make their participants more sensitive to the problem of smog. (barrel alarm of Łaziska website).

It seems that in order to achieve successes in reducing urban smog, it is important to harmonize actions and initiatives undertaken by the government, local government of a given city and by its residents and non-governmental organizations operating on its territory. In the case of Mikołów, these relationships are visible. The Polish state, adapting to the EU requirements regarding the level of pollution, implements an environmental policy, which includes reducing low emissions in cities and thus the phenomenon of urban smog. This ecological policy is reflected by the government program CLEAN AIR, which includes social campaigns aimed at sensitizing urban residents to the problem of urban smog, and a subsidy program for the replacement of traditional coal furnaces with fifth generation coal or gas furnaces (Shakhil, 2018) carried out for two years. Mikołów, and especially its authorities, promote the possibility of using the above-mentioned subsidies. In this area, activities carried out by the Polish government meet with the activity of the municipal authorities of Mikołów.

For many years, Mikołów has been independently implementing investments that have an impact on reducing low emissions. These activities were presented in a case study and relate to the modernization of municipal boiler rooms, expansion of the heating network, conducting thermo-modernization of housing estates and taking actions to encourage residents to use public transport more often. The weakness of activities in this respect is the lack of activities encouraging owners of single-family homes to use the heating services of municipal boiler rooms despite a similar heating cost to the cost of gas heating.

Similar mechanisms exist in Slovakia and the analysed city of Żylina. The new ecological policy of Slovakia adopted in 2019 until 2030 takes into account the issue of air pollution and its components are activities related to conducting appropriate activities to reduce the phenomenon of urban smog. In case of Żylina, the assumptions adopted in the field of environmental policy of Slovakia are manifested in the promotion of low-emission transport in this 
city and shaping conditions for its further development, as well as in the reconstruction of the road network to relieve the city centre from the negative effects of excessive car traffic.

\section{Summary}

This article addresses the possibilities of counteracting urban smog and its global negative effects in medium-sized cities. The conducted considerations in this area were referred to Polish and Slovak experiences. In the case of both analysed cities, i.e. Mikołów and Żylina, it can be seen that the measures implemented in this area related to the current ecological policy of the given country on which territory they are located.

In the case of Poland, the main factor in creating urban smog is the so-called low emissions mainly from individual furnaces of home and apartment owners, as well as city boilers. Therefore, Poland is carrying out activities aimed at limiting the scale of this phenomenon. Their expression is the currently implemented government program STOP SMOG, which includes subsidies for replacing old coal furnaces with gas furnaces. The municipal authorities of Mikołów promote the possibility of using this type of subsidies among the residents. An additional investment-related activities related to the modernization of municipal boiler rooms or expansion of the heating network, as well as thermo-modernization of blocks. Also the social perspective related to the change in the behaviour of residents regarding the methods of using coal furnaces, as well as their transition to gas heating is important in this respect. The social perspective also includes the activity of local government organizations or municipal guard initiatives to educate residents of Mikołów about the risks of smog and change their attitudes regarding burning plastic waste in furnaces and teach them the socalled top burning.

In turn, taking into account the specificity of Slovakia, its main problem related to the occurrence of smog is primarily public transport and road traffic. The presented phenomena can be seen in the case of Żylina. However, actions are being taken in this city to promote electro-mobility, increasing the amount of green areas absorbing pollution, and road investments to relieve the city centre from air pollution resulting from excessive vehicle traffic.

It should be assumed that Poland, being successful in reducing low emissions, which is the main source of smog in this country, will benefit from Slovak experience focusing on issues of electro-mobility development and reducing excessive road traffic.

Despite comprehensive measures implemented in Poland to reduce the phenomenon of smog and their visible positive effects, an important limitation of their effectiveness is the economic barrier to the transition to more ecological forms of heating for many households. This situation results from the price of coal in Poland, which means that it is currently the cheapest carrier of heat energy. The cost of gas heating in Poland is 20-30\% more expensive compared to heating with coal. Following the example of Slovak solutions, it may be necessary to introduce special, reduced tariffs for owners of electric furnaces for heating in Poland, and promote the connection of property owners to municipal heating networks operating in many Polish cities.

\section{References}

1. CZUBA M., 2018, Promotion of Proecological initiatives In Polish Cities. Case Study of Mikołów Municipality, in: International Journal of New Economics and Social Sciences, 8 (2), p. 347-357.

2. DEMSKI M., 2016, Mikołów: strażnicy miejscy $i$ strażacy pokazali, jak palić oszczędnie i ekologiczne, https://dziennikzachodni.pl/mikolow-straznicy-miejscy-i-strazacy-pokazali-jak-palic-oszczednie-i-ekologiczne/ar/11456114 (13.04.2019).

3. GALLET S., 2018, Six NGOs Fighting Air PollutionGetting Involved, https://blog.breezometer.com/ngos -fighting-air-pollution (20.04.2019).

4. Greener Slovakia. Strategy of the Environmental Policy of the Slovak Republic until 2030, 2019, https:// www.minzp.sk/files/iep/greener_slovakia9-strategy_ of_the_environmental_policy_of_the_slovak_republic_until_2030.pdf (20.11.2019).

5. HERNANDEZ R. A., 2015, Prevention and Control of Air Pollution in China: A Research Agenda for Science and Technology Studies, in: S.A.P.I.EN.S, 8.1, http://journals.openedition.org/sapiens/1734 (16. 04.2019).

6. LOGINOW K., 2017, Samochodowe piekto. Żylina to nie jest miasto dla pieszych i rowerzystów, https://sm oglab.pl/zylina-samochodowe-pieklo/ (4.11.2019).

7. KRYŻANOWSKI M., 2008, WHO Air Quality Guidelines for Europe, in: Journal of Toxicology and Environmental Health, Part A 71(1), p. 47-50.

8. MACHOWSKI J., 2003, Ochrona środowiska. Prawo i zrównoważony rozwój (Stan prawny na dzień 1 stycznia 2003 r.), Wyd. Akademickie Żak, Warsaw 2003, p. 100-101.

9. MALEC A., BORKOWSKI G., 2016, Zagrożenia pyłowe oraz monitorowanie powietrza atmosferycznego, in: Ecological Engineering, 50, p. 161-170.

10. MELAMED M., ZHU T. JALKANEN L., 2013, Urban air pollution: a new look at an old problem, http://www.igbp.net/news/features/features/urbanair pollutionanewlookatanoldproblem.5.19895cff13e9f6 75e253f0.html (14.04.2019).

11. OECD, 2012, OECD Environmental Outlook to 2050: The Consequences of Inaction, DOI: 10.1787/9789264122246-en.

12. PŁATKOWSKA-PROKOPCZYK L., 2017, The Level of Environmental Awerness as a Determinant of Attitudes and Behaviors Developed by Inhabitants of Towns and Villages - A Comparative Case Study, in: Infrastructure and Ecology of Rural Areas, IV(2), Polish Academy of Sciences, Cracow, p. 1633-1647.

13. Poprawa jakości powietrza atmosferycznego $w$ mieście Mikołów - modernizacja kottowni przy ul. Gra żyńskiego http://www.zim.com.pl/?jezyk=pl\&grupa $=9 \& \mathrm{dzi}=12774575 * 67 \&$ art. $=1277462723 \&$ id_menu. 
14. Poprawa jakości powietrza atmosferycznego w mieście Mikołów - modernizacja kołowni przy ul. Grażyńskiego, 2019, http://www.zim.com.pl/?jezyk=pl $\&$ grupa $=9 \& \mathrm{dzi}=12774575 * 67 \&$ art. $=1277462723 \&$ id_menu (14.4.2019).

15. RHODE A, MULLER R. A., 2015, Air Pollution in China: Mapping of Concentrations and Sources, in: PLOS ONE, https://journals.plos.org/plosone/article ?id=10.1371/journal.pone. 0135749 .

16. RHODE R. A, MULLER R. A., 2015, Air Pollution in China: Mapping of Concentrations and Sources, in: PLOS ONE, https://journals.plos.org/plosone/article ?id=10.1371/journal.pone.0135749 (16.04. 2019).

17. SHAKHIL S., 2018, Poland finally realises it has to deal with its pollution problem, https://emerging-europe.com/news/poland-finally-realises-it-has-to-deal -with-its-pollution-problem/

18. (25.04.2019).

19. SHINDELL D. et al., 2012, Science, 355, p. 183-189. State of Global Air 2019 - A Special Report On Global Exposure To Air Pollution \& Its Disease Burden, in: Science, 255 p. 183-189, https://www.state ofglobalair.org/sites/default/files/soga_2019_report. pdf (13.11.2019)

20. SKOWROŃSKI A., 2006, Zrównoważony rozwój perspektywą dalszego postępu cywilizacyjnego, in: Problemy Ekorozwojul Problems of Sustainable Development, 1(2), p. 47-57.
21. Smog - jeden z najważniejszych czynników ryzyka zdrowotnego w Polsce, 2017, in: Sustainability Insights, https://www2.deloitte.com/pl/pl/pages/ zarzadzania-procesami-i-strategiczne/articles./sustainability-insights/smog-zdrowie-polska.html (13.11.2019).

22. Smogowa edukacja dla nauczycieli z powiatu mikotowskiego, https://laziski.alarmluftowy.pl/index. php/ 2019/03/25/smogowa-edukacji-dla-nauczycieli-z-po wiatu-mikolowskiego/ (30.04.2019)

23. Straż Miejskia miasta Mikołów, http://www.strazmiejska.mikolow.eu. (30.04.2019).

24. Uchwała Rady Ministrów z dnia 16 lipca 2019 r. w sprawie przyjęcia Polityki ekologicznej państwa 2030 - strategia rozwoju w obszarze środowiska i gospodarki wodnej, M.P.2019, 794

25. UN, 2015, Sustainable Development Goals, New York.

26. Urząd Miasta Mikołów, Mikołów: chcemy stać się eko-gminą, https://www.teraz-srodowisko.pl/aktualnosci/Mikolow-chcemy-stac-sie-eko-gmina-4308.ht $\mathrm{ml}$ (13.04.2019).

27. ZHOU L., DAI Y., 2017, How Smog Awareness Influences Public Acceptance of Congestion Charge Policies, in: Sustainability, 9, p. 1579.

28. Zmiana klimatu a powietrze, https://www.eea.europa.eu/pl/sygna142y/sygnaly-2013/artykuly/zmiana -klimatu-a-powietrze (13.11.2019). 
